\title{
TREX2 wt Allele
}

National Cancer Institute

\section{Source}

National Cancer Institute. TREX2 wt Allele. NCI Thesaurus. Code C51010.

Human TREX2 wild-type allele is located within Xq28 and is approximately $26 \mathrm{~kb}$ in length.

This allele, which encodes three prime repair exonuclease 2 protein, is involved in several

DNA metabolic pathways. 